IBIMA Publishing

Journal of Eastern Europe Research in Business and Economics

http://ibimapublishing.com/articles/JEERBE/2021/325285/

Vol. 2021 (2021), Article ID 325285, 8 pages, ISSN: 2169-0367

DOI: $10.5171 / 2021.325285$

Research Article

\title{
Causes of Contemporary Migrations
}

\author{
Wojciech Szczepan STASZEWSKI \\ University of Szczecin, Szczecin, Poland \\ wojciech.staszewski@usz.edu.pl; \\ https://orcid.org/0000-0002-4139-3475
}

Received date:15 April 2020; Accepted date: 9 June 2020; Published date: 11 June 2021

Academic Editor: Júlia Kostrová

Copyright (C 2021. Wojciech Szczepan STASZEWSKI. Distributed under Creative Commons

Attribution 4.0 International CC-BY 4.0

\begin{abstract}
Migrations, permanently inscribed in the history of human development, have been and are determined by a number of factors. This paper, the aim of which is to demonstrate the current causes of migrations, sets out to settle the formulated research questions concerning the main contemporary factors of movement of people and to point to conditions which may affect these processes occurring in the future. It analyses social and economic factors (including the issues of development disproportions between countries, food problems, debt issues), technological, demographic, political as well as those associated with the occurring changes in man's natural environment. A hypothesis has been formulated, in accordance with which we are increasingly dealing with the fact that individual factors determining the movement of people permeate, which affects the impossibility of a clear indication of its specific cause. The hypothesis was verified positively.
\end{abstract}

Keywords: Migrations, International Migrations, Causes of Migrations, Determinants of Migrations, Climate Migrants, SARS-Cov-2 Pandemic.

\section{Introduction}

Migrations, falling under multidimensional phenomena of various characters (demographic, economic, social, political, cultural) and as such, a subject of research of many scholarly disciplines (e.g. demography, sociology, legal studies, economy), have existed for thousands of years and are permanently associated with human history [Keeley writes about migration processes in the past (Keeley,
2019, p. 21ff)]. They have been and are determined by numerous factors, though as pointed out by A. Maryański, "migrations are, by nature, a vigorous element dependent on many incalculable factors" (Maryański, 1984, p. 10). One can conclude that they are a resultant of numerous social and economic circumstances (SzajnowskaWysocka, 2000, p. 28). In the historical development, migrations have changed their character and intensity multiple times.

Cite this Article as: Wojciech Szczepan STASZEWSKI (2021)," Causes of Contemporary Migrations", Journal of Eastern Europe Research in Business and Economics Vol. 2021 (2021), Article ID 325285,

DOI: $10.5171 / 2021.325285$ 
This paper, the aim of which is to demonstrate the current causes of migrations, sets out to settle the formulated research questions concerning the main contemporary factors of movement of people and to point to conditions which may affect these processes occurring in the future. This analysis is done with the assumption that this study addresses international migrations with their broad understanding, thus undertaken as the movement of people from one country to another for a temporary or permanent stay, freely or under coercion (Cziomer, 1999, p. 77). The causes of the described phenomenon, which the authors of this paper dealt with in distant past, will stay outside the scope of this study. It seems obvious that since the dawn of time, people have moved in response to a demographic growth, climatic changes or expansion of production and trade (Castles, Miller, 2011, p. 107). Contemporary migrations and their causes are a certain consequence of various factors which occurred in the 20th century, a century called "the age of migrations" by S. Castles and M. J. Miller (Castles, Miller, 1998). It needs to be borne in mind that the intensification of processes associated with movement of people in the $20^{\text {th }}$ century entailed unprecedented development of infrastructure, means of transport and media as well as an economic upturn. It was also associated with the result of the activity of two totalitarian regimes and two world wars which caused mass flights or displacement and deportation of people of unparalleled volumes. The migration waves in the second half of the 20th century did not weaken, and in certain periods, even intensified. It was caused by new international circumstances which contributed to the migration wave, i.e. decolonization, post-war economic development, demand for cheap labour, armed conflicts, as well as political and religious persecutions. It was noted that more often than before, migrations gained a multiple character - migrants change their countries of residence multiple times during their lifetime (Wójcik-Żołądek, 2014, p. 10).

Social and economic factors of
migrations

Social and economic factors are undoubtedly essential causes of contemporary migrations. Particular attention needs to be paid, in this regard, to the severe disproportions between the level of economic development of individual countries and their groups. It is pointed out that the consequence of the development asymmetries involves great differences in standards and quality of life between different countries and regions (Sulmicka, 2001). To illustrate the "development gap", with regard to economic and social and civilisation development in the West-South relations, one needs to point out that in 1990 , the West, which accounts for $15.7 \%$ of the population, produced $71.7 \%$ of the gross world product, while post-communist countries accounted for $7 \%$ of the population - produced $12.3 \%$ of the GWP, and the South, representing $77.3 \%$ of the world population produced only $16.1 \%$ of the gross world product. One needs to point out that this "development gap" has not narrowed significantly despite world scale efforts (since the 1960s, the so-called UN development decades have been undertaken in this scope). The 1999 United Nations Development Programme - UNDP entitled "Human Development Report 1999" pointed out that differences in incomes between the $20 \%$ of the population who live in developed countries and the $20 \%$ living in the least developed countries were 30:1 in $1960,60: 1$ in 1990 and in 1997, it reached $74: 1.86 \%$ of the gross world product fell for those $20 \%$ of the richest populations, while a mere $1 \%$ for the poorest. The Report demonstrated that the OECD countries with $19 \%$ of the global population had $71 \%$ of global trade in goods and services, $58 \%$ of global foreign direct investment, and $91 \%$ of all Internet users (UNDP, 1999).

The UNDP created (as highlighted) a more comprehensive, though subjective, so-called human development index - HDI, with the scale from 0 to 1 , which takes into account, apart from the economic aspect (real purchasing power of the obtained income per capita), also certain social and civilisation aspects of this development (such as life expectancy, literacy index) (Tabor, 2000, p. 276). Based on this index, 
the UNDP published, in 1990, the first ranking of 130 countries with a population of at least 1 million, in which the top places were occupied by the so-called countries of the West (Japan in the first place -0.996), whereas the last positions were taken by African countries (last place - Niger 0.116) (Tabor, 2000, p. 276). In the last ranking published by the UNDP, enumerating 189 countries, the first twenty places are taken by: Norway (0.954), Switzerland (0.946), Ireland (0.942), Germany (0.939), Hong Kong [China] (0.939), Australia (0.938), Iceland (0.938), Sweden (0.937), Singapore (0.935), Netherlands (0.933), Denmark (0.930), Finland (0.925), Canada (0.922), New Zealand (0.921), United Kingdom (0.920), United States (0.920), Belgium (0.919), Liechtenstein (0.917), Japan (0.915) and Austria (0.914). Whereas the following countries are at the bottom of the list (starting from the end): Niger (0.377), Central African Republic (0.381), Chad (0.401), South Sudan (0.413), Burundi (0.423), Mali (0.427), Eritrea (0.434), Burkina Faso (0.434), Sierra Leone (0.438), Mozambique (0.446), Congo (Democratic Republic of the Congo) (0.459), GuineaBissau (0.461), Yemen (0.463), Liberia (0.465), Guinea (0.466), Gambia (0.466), Ethiopia (0.470), Malawi (0.485), Djibouti (0.495) and Afghanistan (0.496) (UNDP, 2019). This data shows that the situation stays unchanged, the so-called Western countries still occupy the top spots and African countries take the last places.

The subject matter of development disproportions also covers raw materialsenergy questions, food problems and international debt issues (Tabor, 1994, p. 144). There is no doubt that raw materials and energy determine economic development, which is why the possibilities of using raw materials, which are key to the economic and civilisation development, and the energy derived from them are treated as a key factor of long-term growth. The existing disproportion between "resources" and "needs" is also the reason for interdependence of countries and sometimes may lead to crises and disputes, or even international conflicts (Stadtmüller, 2000, pp. 21 4-219).
Food problems are also marked with a great imbalance between individual countries and regions. Some countries have a problem to manage food surpluses, while others do not have enough food to cover basic social needs. Food production is mainly determined by resources and natural functions, by the area of arable land, adequate resources of fresh water and wellfunctioning ecosystems. The 2019 report "The State of Food Security and Nutrition in the World (Safeguarding against Economic Slowdowns and Downturns)" shows that more than 820 million people in the world suffer starvation. It was also pointed out that after many years of a decline, the number of undernourished people began to rise again in 2015, and compared with this in 2017, the number of people suffering from starvation rose by over 11 million. It seems that the goal specified in the $2030 \mathrm{UN}$ Agenda for Sustainable Development (United Nations General Assembly, 2015, p. 14), involving total elimination of severe poverty in any form throughout the world, seems too ambitious and difficult to implement.

It needs to be borne in mind that in the areas where there is a food deficit, social distress often occurs, and when this problem increases, it may pose a risk of armed conflicts for access to fertile soils and water (Stadtmüller, 2000, p. 213).

Examining debt issues, one may agree with the view that it is not a problem until debtors, for various reasons, are not able to settle obligations towards their creditors on time. However, the more countries-debtors stray away from the so-called safety boundary, the more the problem grows, that is when the annual service of foreign debt exceeds $25 \%$ of the value of the annual export and the amount of payment of the annual interest exceeds $10 \%$ of this export (Tabor, 1994, p. 154). This has been pointed out since the beginning of the 1970s. The level of foreign debt of developing countries has been constantly on the rise (Górniewicz, 2010 , p. 69ff). It needs to be noted that the growth of debt in the world may lead to a financial crisis or even chaos. Despite the various actions taken in order to lower debt in the world, the chances of eliminating all 
related threats are limited (Tabor, 1994, pp. 153-156).

Taking into consideration social and economic contexts, one cannot leave out the psychological factor in perceiving objective differences in the level of development of societies. The perception of the economic situation and of the perspectives of the development of one's country, the assessment of the capabilities and opportunities for an individual's progression and professional career, the hope for personal success or the sense of security, as well as the faith (or its lack) in stabilisation and a "better tomorrow" are also essential (Kozanecka, 1997, p. 201). It is pointed out that in a situation where pessimism prevails, migration pressure rises for obvious reasons (Anioł, 1992, p. 23).

\section{Technological factors of migrations}

Technological factors also play a crucial role among determinants of contemporary migrations. Modern means of transport and developed communication networks allow an easy, quick and relatively inexpensive movement of vast masses of people from one country or continent to another. It is one of the key factors of the observed migrations' acceleration. One may agree with the view that without modern means of transport and well-developed communication networks, the great "migration of peoples" observed in recent decades would have been practically impossible (Anioł, 1992, p. 23).

\section{Demographic factors of migrations}

Demographic factors are now an important group of determinants which affect mass migrations. The speed of population growth in each country causes various consequences, both when it is low and when it is high. When analysing demographic data, a number of worrying phenomena were noted, e.g. a significant population growth has been observed since the 1950s, where the pace of growth of the population of under-developed countries is much higher than that of developed countries. It was assumed that should current trends be maintained, in 2050, world population will exceed 10 billion, where $95 \%$ of this growth will fall for today's countries of the South (Tabor, 2000, p. 265 and Cesarz, 2000, pp.163-167). One needs to take into account that the changes in the distribution of the world population are also associated with a vigorous influx to cities (Cesarz, 2000, p. 167-168). A rapid growth in populations of large cities such as Mexico City, Shanghai or Mumbai is also concerning (Mojsiewicz, 1997, p. 211).

It is also worth noting that demographers point to an unfavourable structure of the age of the population (Mojsiewicz, 1997, p. 211). The average age at the moment is as follows: in Europe - 42.4; in North America - 39.7; in Oceania - 35.8; in Asia - 33, 8; in South America - 33. 2, and in Africa - 24, 1 (World Population, 2020). This data clearly shows that developed countries located in Europe or North America belong to "the aging societies" compared to underdeveloped countries in Africa, Asia or South America. One may agree with the belief that the geography of demographic asymmetries overlaps with the geography of developmental disproportions (Tabor, 2000 , p. 265). The ageing societies of developed countries and often a low or negative birth rate also cause demand for labour. Thus, these countries often conduct a well-thought out migration policy in this regard, the aim of which is, to manage migration processes and use them in the development of a given country. In these countries, the supply of labour often depends on the inflow of immigrants (Matkowska, 2013, p. 77).

At the moment, it is not known what impact the pandemic caused by the SARS-CoV-2 virus will have on demography. It may significantly affect the demographic situation of many countries, but without a doubt it, will influence the economic situation in the world.

\section{Political factors of migrations}

Political factors still take a significant place among the factors of contemporary migrations - political upheavals, political instability of certain countries established 
after WWII, and armed conflicts. Causes of emigration also include discrimination and persecution of national minorities, for political and religious reasons and due to sexual orientation and others. The causes for a decision to change one's place of residence also include reasons associated with limitation of fundamental human rights.

The data from the United Nations High Commissioner for Refugees demonstrates that in 2018, more than 70 million people were forced to leave their place of residence, and in 2009, this number was over 43 million (UNHCR, 2018, p. 4).

It also needs to be noted that the choice of a place of residence is associated with the migrant's personal experience. He does not accept the political system of the country he currently lives in and for this reasons takes a decision to change his place of residence.

\section{Environmental factors of migrations}

When presenting determinants of contemporary migrations, one cannot omit the factor associated with negative changes in the natural environment. Vast numbers of people leave their places of residence due to the degradation of the natural environment and a change in its conditions or climate. Many world regions, due to i.a. lack of water, water pollution, desert terrains or degradation of farmlands due to excessive exploitation or deforestation, are not fit for human habitation. It is assumed that if a given country has less than 1,000 cubic meters of water per person throughout the year, it suffers water shortages, which severely hampers economic development and negatively affects human health (Przyszłość, 1999, p. 53). In 1990, 20 countries were in such a position, whereas in 2025, they are to reach 30 (Przyszłość, 1999, p. 53).

It is worth noting that the concept of "climate migrants" was first used in the 1980 s in reference to people forced to leave their natural place of residence due to such changes to the natural environment which led to a threat to their life and health (Groszkowska, 2019, p. 241-242).
The issues concerning the impact of climate changes on the phenomenon of migrations were the subject of interest of the Intergovernmental Panel on Climate Change (IPCC) under the United Nations, which in 2007, published a report (IPCC, 2007) where it was pointed out that climate changes will proceed even more quickly and in consequence, the number of people exposed to extreme weather phenomena, rising sea and ocean levels and other climatic threats will rise, which in turn will bring about a growth in migration (Groszkowska, 2019, p. 242).

In the 2004 IPCC report (IPCC, 2014), a distinction was made between two types of migration associated with climate change, namely: 1 . Caused by extreme weather events (their frequency will increase with the occurring climate changes) and 2 . Caused by long-term changes in the natural environment, such as rising sea levels which will flood little island states and will force residents to resettle. The report from the UN High Commissioner for Human Rights (HRC, 2018) also refers to this division, where it classifies events into sudden onset events (hurricanes, storms, and flooding) and slow onset events (sea level rise, increasing temperatures, ocean acidification, glacial retreat, salinization, land and forest degradation, loss of biodiversity, and desertification). This division was also upheld in a 2019 document adopted by a way of intergovernmental negotiations drawn up under the auspices of the UN entitled Global Compact for Safe, Orderly and Regular Migration (United Nations General Assembly, 2019).

These events were explained in the document "Slow onset events - Technical paper" (FCCC, 2012). The first ones ("rapid onset events") include single, discrete events that occur in a matter of days or even hours. Whereas the other ones ("slow onset events") evolve gradually from incremental changes occurring over many years, or from an increased frequency or intensity of recurring events. 
One also needs to take into consideration that the impact of environmental factors on people's mobility is undoubtedly a complex phenomenon and often occurs in relation to social, economic or political factors (Groszkowska, 2019, p. 242).

\section{Summary}

To sum up, one can conclude that contemporary migrations are determined by numerous political, cultural, social, economic factors and those associated with the degradation of man's natural environment. Individual reasons for migrations permeate increasingly, especially that they are strictly interrelated, which is why it is often difficult to classify unequivocally a specific reason for a given movement of people. Without a doubt, the most severe effects causing migrations will still be brought about by the rising disproportion in the social and economic development of the world's countries and emerging conflicts in the world, or by the factors of man's natural environment, which in the long run, may lead to the disappearance from the world map of some island states. At the moment, it is impossible to fully understand the conditions and changes occurring in individual countries and regions without reference to the global context. The existing interrelations of the impact of participants of the global system of international relations are a consequence of the common occurrence of processes of internationalization of various spheres of social life. Today, it is also impossible to predict the impact of the pandemic caused by the SARS-CoV-2 virus. It will gravely influence the social and economic situation of countries and may bring about an increased demand of developed countries for highly-qualified labour force, which in turn, may contribute to the ample one-way migration flow of highly-qualified staff, and to the "draining" of poorer countries of the most valuable factor of development that is human resources, especially highlyqualified staff.

In the course of research, the assumed hypothesis was verified positively, concluding that we are increasingly dealing with the fact that individual factors determining the movement of people permeate, which affects the impossibility of a clear indication of its specific cause.

\section{Foot Note}

Migrations : *The text was presented (as a virtual presentation) at the 35th International Business Information Management Association Conference (IBIMA) and published as Causes of contemporary migrations, [in:] Khalid S. Soliman (ed.), Education excellence and innovation management: a 2025 vision to sustain economic development during global challenges: Proceedings of the 35th International Business Information Management Association Conference (IBIMA) 1-2 April 2020 Seville, Spain, ISBN 978-0-9998551-4-1, pp. 17878-17884. The author has been researching the issues of migrations for years and has published works that address this topic, i.e. Przyczyny i skutki współczesnych migracji międzynarodowych, "Cogitatus: zeszyty naukowe" 2007, no. 4, pp. 106-128; Pojęcie migracji międzynarodowych, "Cogitatus: zeszytynaukowe" 2008, no. 5, pp. 14-24; Zagadnienia migracji ludności w konwencjach Rady Europy, "Studia Prawnicze KUL” 2009, no. 1, ISSN 18977146, pp. 119-131.

\section{References}

- 'Przyszłość w liczbach. Prognozy' (1999), Deutschland, 6, 53.

- Anioł, W. (1992), Migracje międzynarodowe a bezpieczeństwo europejskie, Instytut Studiów Politycznych Polskiej Akademii Nauk, Warszawa.

- $\quad$ Castles, S. and Miller, M.J. (1998), The Age of Migration. International Population Movements in the Modern World, Palgrave, London.

- Castles, S. and Miller, M.J. (2011), Migracje we współczesnym świecie, Gąsior-Niemiec, A. (trans.), Wydawnictwo Naukowe PWN, Warszawa.

- Cesarz Z. (2000), Wpływ czynnika demograficznego na środowisko międzynarodowe, Problemy polityczne współczesnego świata, 
Cesarz, Z. and Stadtmüller, E. (eds.),Wydawnictwo Uniwersytetu Wrocławskiego, Wrocław.

- Cziomer, E. (1999), Wybrane problemy migracji w Polsce w latach dziewięćdziesiątych, Polska - Niemcy - Ukraina w Europie: modele dla euroregionów Środkowowschodniej Europy, jak wychowywać dla Europy, Bonusiak, W. (ed.), Wydawnictwo Wyższej Szkoły Pedagogicznej, Rzeszów.

- $\quad$ FAO (2019), The State of Food Security and Nutrition in the World. Safeguarding Against Economic Slowdowns and Downturns. Food and Agriculture Organization of the United Nations, Rome.

- FCC (2012), United Nations Framework Convention on Climate Change, Slow onset everts - Technical paper, FCCC/TP/2012/7.

- Górniewicz, G. (2010), 'Ameryka Południowa wobec problemu zadłużenia zagranicznego', Toruńskie Studia Międzynarodowe. Międzynarodowe Stosunki Ekonomiczne, 1(3), 69-86.

- Groszkowska, K. (2019), 'Migranci czy uchodźcy? Prawne aspekty ochrony osób migrujących ze względu na negatywne zamiany środowiska naturalnego', Studia BAS, 4(60), 241259.

- HRC (2018), The Slow onset effects of climate change and human rights protection for cross-border migrants. Annual report of the United Nations High Commissioner for Human Rights and reports of the Office of the High Commissioner and the SecretaryGeneral, A/HRC/37/CRP.4.

- IPCC (2007), Climate Change 2007: Impacts, Adaptations and Vulnerability. Contribution of Working Group II to the Fourth Assessment Report of the Intergovernmental Panel on Climate Change, Parry, M., Canziani, O., Palutikof, J., van der Linden, P. and Hanson, C. (eds.), Cambridge University Press, New York.

- IPCC (2014), Climate Change 2014: Impacts, Adaptations, and Vulnerability. Working Group II
Contribution to the Fifth Assessment Report of the Intergovernmental Panel on Climate Change, Field, C.B., Barros, V.R., Dokken, D.J., Mach, K.J., Mastrandrea, M.D., Bilir, T.E., Chatterjee, M., Ebi, K.L., Estrada, Y.O., Genova, R.C, Girma, B., Kissel, E.S., Levy, A.N., MacCracken, S., Mastrandrea, P.R. and White, L.L. (eds.), Cambridge University Press, New York.

- Keeley, B. (2019), International Migration: The Human Face of Globalisation, OECD.

- Kozanecka M. (1997), Czynniki pobudzające migracje transgraniczne i problemy z nimi związane, Społeczne koszty migracji transgranicznej,Kitowski, J. (ed.), Uniwersytet Marii CurieSkłodowskiej, Filia w Rzeszowie, Wydział Ekonomiczny, Rzeszów 1997.

- $\quad$ Maryański, A. (1984), Migracje w świecie, Państwowe Wydawnictwo Naukowe, Warszawa.

- Matkowska, M. (2013), 'Polska polityka migracyjna - zarys problemu', Zeszyty Naukowe Uniwersytetu Szczecińskiego. Studia i Prace Wydziału Nauk Ekonomicznych i Zarzq̨dzania, 33(1) - Gospodarka regionalna i międzynarodowa, 77-92.

- Mojsiewicz C. (1997), Problemy globalne, Międzynarodowe stosunki polityczne, Malendowski, W. and Mojsiewicz, C. (eds.), Wydawnictwo Fundacji Humaniora, Poznań.

- Stadtmüller, E. (2000), Kwestie żywnościowe i surowcowe we współczesnym świecie, Problemy polityczne współczesnego świata, Cesarz, Z. and Stadtmüller, E., (eds.), Wydawnictwo Uniwersytetu Wrocławskiego, Wrocław.

- Sulmicka, M. (2001), Ubóstwo we współczesnym świecie, Oficyna Wydawnicza SGH, Warszawa.

- Szajnowska-Wysocka, A. (2000), Aspekty i walory metodologiczne zjawiska migracji, Procesy i formy ruchliwości przestrzennej ludności w okresie przemian ustrojowych, Szymańska, D. (ed.), Uniwersytet Mikołaja Kopernika, Toruń. 
- Tabor, M. (1994), Problemy globalne, Stosunki międzynarodowe: geneza, struktura, funkcjonowanie, Haliżak E. and Kuźniar, R. (ed.), Wydawnictwo Uniwersytetu Warszawskiego, Warszawa.

- Tabor, M. (2000), Problemy globalne, Stosunki międzynarodowe: geneza, struktura, funkcjonowanie, Haliżak E. and Kuźniar, R. (eds.), Wydawnictwo Uniwersytetu Warszawskiego, Warszawa.

- UNDP (1999), United Nations Development Programme, Human Development Report 1999, Oxford University Press, New York - Oxford.

- UNDP (2019), United Nations Development Programme, Human Development Report 2019. Beyond income, beyond averages, beyond today: Inequalities in human development in the $21^{\text {st }}$ century, New York.

- UNHCR - The UN Refugee Agency (2018), Report - Global Trends Forced Displacement in 2018.

- United Nations General Assembly (2015), Resolution adopted by the General Assembly on 25 September 2015 - Transforming our world: the 2030 Agenda for Sustainable Development.

- United Nations General Assembly (2019), Global Compact for Safe, Orderly and Regular Migration, A/RES/73/195.

- Wójcik-Żołądek, M. (2014), 'Współczesne procesy migracyjne: definicje, tendencje, teorie', Studia $B A S, 4(40)$, 9-35.

- World Population (2020), [Online] [Retrieved April 5, 2020], https://www.populationof.net/. 